10a Jenkinson C, Coulter A, Wright L. Short form 36 (SF 36) health survey questionnaire: normative data for adults of working age. $B M F$ 1993;306:1437-40.

11 Streiner GL, Norman DR. Health measurement scales: a practical guide to their development and use. Oxford: Oxford University Press, 1990.

12 Cronbach LJ. Coefficient alpha and the internal structure of tests. Psychometrika 1951;16:297-334.

13 Kline P. A handbook of test construction. London: Methuen, 1986

14 Nunnally JC. Psychometric theory. 2nd ed. New York: McGraw-Hill, 1978

15 Child D. The essentials of factor analysis. 2nd ed. London: Cassell, 1990.

16 Colle. Th Principals of

17 Vickrey BG, Hays RD, Graber J, Rausch R, Engel J, Brook RH. A healthrelated quality of life instrument for patients evaluated for epilepsy surgery. Med Care 1992;30:299-312.
18 Stewart AL, Hays RD, Ware JE. The MOS short-form general health survey: reliability and validity in a patient population. Med Care 1988;26:724-33.

19 Armitage P, Berry G. Statistical methods in medical research. 2nd ed. Oxford: Blackwell, 1987.

20 Garratt AM, Macdonald LM, Ruta DA, Russell IT, Buckingham JK, Krukowski $\mathrm{ZH}$. Towards the measurement of outcome for patients with varicose veins. Ouality in Health Care 1993;2:5-10.

21 Ellwood PM. Outcomes management: a technology of patient experience. NEngl Y Med 1988;318:1549-56.

22 Roland MO, Coulter AM. Hospital referrals. Oxford: Oxford University Press, 1992.

(Accepred 19 April 1993)

\title{
Damage to DNA in cervical epithelium related to smoking tobacco
}

\author{
Andrew M Simons, David H Phillips, Dulcie V Coleman
}

Abstract

Objective-To determine whether tobacco smoking causes increased DNA modification (adducts) in human cervical epithelium.

Design-Comparison of DNA adducts measured by the technique of postlabelling with phosphorus-32 in normal ectocervical epithelium of smokers and non-smokers. A questionnaire on smoking habit and a urinary cotinine assay were used to identify smokers and non-smokers.

Setting-Cytology unit in large teaching hospital.

Subjects-39 women (11 current smokers, seven former smokers, and 21 who had never smoked) undergoing gynaecological treatment (colposcopy or hysterectomy). Nineteen members of staff who did not smoke as controls.

Interventions-Biopsy of normal ectocervical epithelium. Urine sample.

Main outcome measures-Measurement of DNA adducts in cervical epithelial tissue of smokers and non-smokers. Smoking habit derived from results of questionnaire and urinary cotinine:creatinine ratio. Proportion of adducts in women with abnormal and normal results of cervical smear test.

Results-DNA samples from smokers (identified from questionnaire) had significantly higher median proportions of DNA adducts that non-smokers (4.62 (95\% confidence interval 4.04 to 7.74$) v 3.47(2.84$ to 4.78) adducts $/ 10^{\circ}$ nucleotides; $\left.p=0.048\right)$. Exclusion of women whose urinary cotinine:creatinine ratio did not confirm their self reported smoking habit (smoker or non-smoker) increased this difference $\left(4.7(3.85\right.$ to 8.08$) \cup 3.52(2.32$ to 4.95$)$ adducts $/ 10^{3}$ nucleotides; $p=0 \cdot 03$ ). Women who had abnormal results of cervical smear tests had significantly higher proportions of adducts than those with normal results (4.7 (3.90 to 8.13) v 3.47 (3.06 to 5.36) adducts $/ 10^{3}$ nucleotides; $p=0.03$ ).

Conclusions-Tobacco smoking by women leads to increased modification of DNA in cervical epithelium, suggesting biochemical evidence consistent with smoking as a cause of cervical cancer.

\section{Introduction}

Numerous epidemiological studies have shown an association between smoking and cervical cancer. ${ }^{1}$ The evidence for this association is based on population and case-control studies. Many of the studies in which other known risk factors for cervical cancer are adjusted for have shown that women who smoke have up to four times higher risk of developing cervical cancer than non-smokers. ${ }^{2}$ These epidemiological studies, however, do not provide the essential molecular evidence to show whether this relation between smoking and cervical cancer is casual or causal. In 1986 the International Agency for Research on Cancer (IARC) reviewed the available epidemiological data and concluded that there was insufficient evidence at that time to include smoking as a causal agent of cervical cancer. ${ }^{3}$

Many chemical carcinogens exert their biological activity through covalent modification of DNA to form adducts. In the human respiratory tract, where the association between smoking and cancer is unequivocal, ${ }^{3}$ it has been clearly shown that DNA from smokers has significantly higher proportions of adducts than that of non-smokers. ${ }^{47}$ Also cotinine, a metabolite of nicotine, has been detected in the cervical mucus of women, showing that the cervical epithelium is exposed to components of tobacco smoke. $^{89}$

We investigated the presence of DNA adducts in normal squamous cervical epithelium by using postlabelling with phosphorus- 32 and compared the results with the smoking habits of the women.

\section{Subjects and methods}

Women requiring a hysterectomy for benign disease or colposcopy after abnormal results of a cervical smear test were recruited into the study. They were interviewed on admission and asked to complete a questionnaire which asked whether they had ever (currently or previously) smoked. If so, then the length of time they had smoked, the number of cigarettes they smoked a day, and last time they smoked were recorded. Women who reported that they had never smoked were recorded as such. All women were asked whether they had smoked in the preceding 48 hours. Questions on passive exposure to tobacco carcinogens and general health were included. Approval from an ethical committee and informed consent were gained for participation in the study.

A urine specimen was collected at the time of interview to assay for cotinine. The $\mathrm{pH}$ was recorded and the sample frozen at $-20^{\circ} \mathrm{C}$ until analysis. Urine samples were also collected from 19 medical staff (known non-smokers) to act as controls.

A punch biopsy specimen of normal ectocervical epithelium (acetowhite negative areas) was obtained from each woman undergoing colposcopy. A biopsy specimen of ectocervical epithelial tissue (about $6 \mathrm{~mm} \times 10 \mathrm{~mm}$ ) was excised from the anterior lip of the cervices of women who had a hysterectomy. The samples were frozen immediately and stored at $-20^{\circ} \mathrm{C}$ until analysis.

DNA extraction-DNA was isolated from thawed biopsy specimens essentially as described previously. ${ }^{10}$ The DNA yield from each sample was determined spectrophotometrically.

${ }^{32} P$ postlabelling-Samples of $4 \mu \mathrm{g}$ of DNA were
Correspondence to:

Professor Coleman.

BMF 1993;306:1444-8 
digested with micrococcal nuclease and spleen phosphodiesterase then extracted with butanol in an enhancement process as described previously." Butanol phase residues were ${ }^{32} \mathrm{P}$ postlabelled ${ }^{42}$ by incubation with $\left(\gamma-{ }^{32} \mathrm{P}\right)$ ATP (ICN Biochemicals, High Wycombe, Buckinghamshire) and T4 polynucleotide kinase. The reaction was stopped by addition of apyrase. Resolution of ${ }^{32} \mathrm{P}$ labelled adducts was carried out by multidirectional chromatography on polyethyleneimine-cellulose thin layer chromatography sheets by using solvents and directions described previously": firstly, $1 \mathrm{M}$ sodium phosphate, $\mathrm{pH}$ 6 (overnight, on to a filter paper wick); secondly, $3.5 \mathrm{M}$ lithium formate-8.5M urea, $\mathrm{pH} 3.5$ (opposite direction to first direction); thirdly, $0.8 \mathrm{M}$ lithium chloride $-0.5 \mathrm{M}$ TRIS-hydrochloric acid-8.5M urea, $\mathrm{pH} 8\left(90^{\circ}\right.$ to second direction); and fourthly, $1 \cdot 7 \mathrm{M}$ sodium phosphate, $\mathrm{pH} 6$ (on to filter paper wick same direction as third direction). Detection of radioactive material on the chromatograms (after removal of origin area) was by autoradiography at $-75^{\circ} \mathrm{C}$. The areas of the chromatograms containing the radioactive material were excised and assayed for radioactivity by Cerenkov counting. An area of the chromatograms not containing appreciable radioactivity was also excised and counted to provide a background level. The extent of DNA modification was calculated from the levels of radioactivity on the relevant areas of the chromatograms and the specific activity of the $\left(\gamma-{ }^{32} \mathrm{P}\right)$ ATP.${ }^{13}$ The results are expressed as total DNA adducts per $10^{8}$ nucleotides.

Cotinine assay-The procedure for extracting cotinine from urine was a modification of a gas chromatography method (M Sian, personal communication).$^{14} \mathrm{~A}$ sample of $2 \mathrm{ml}$ of urine was mixed with $1 \mathrm{ml}$ $5 \mathrm{M}$ sodium hydroxide and $2.5 \mathrm{ml}$ dichloromethane. The layers were separated by centrifugation and the aqueous phase removed. The organic phase was transferred to a clean Pyrex tube and evaporated under nitrogen at $40^{\circ} \mathrm{C}$. The residue was reconstituted in $100 \mu$ isopropyl alcohol. A $1 \mu$ l aliquot of solution was automatically injected into the gas chromatography column. The analyser used was a capillary gas chromatography unit (Model 3500, Varian Associates) with a $15 \mathrm{~m}$ capillary megabore column (Jones Chromatography) connected to a thermionic specific detector. A routine creatinine assay was carried out on the samples and the results expressed as the urinary cotinine: creatinine ratios (nmol: $\mu \mathrm{mol}$ ).

Method of analysis-Women were classified as smokers or non-smokers both on the basis of their self reported smoking habit and according to their urinary cotinine:creatinine ratio. The proportions of DNA adducts in women who smoked were compared with those of non-smokers. In addition the proportions in

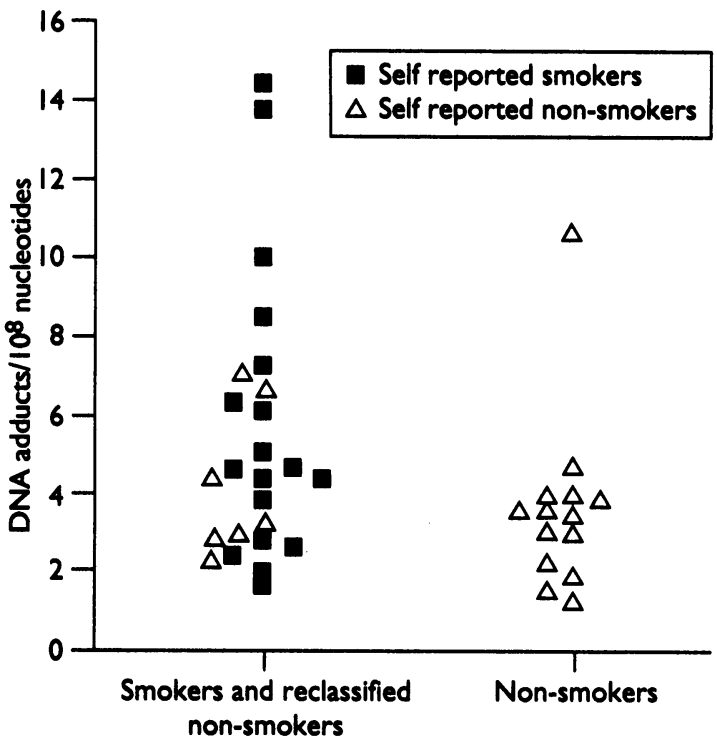

FIG 2-Proportions of DNA adducts of self reported smokers and those non-smokers reclassified as smokers (as result of urinary cotinine: creatinine ratio $>0.06$ ) with non-smokers

biopsy specimens from women with an abnormal result on a cervical smear test were compared with those from women with normal results.

Statistical calculations-To investigate the hypothesis that smoking results in a higher proportion of adducts in cervical epithelium we used the two tailed MannWhitney U test.

\section{Results}

Forty women (age range 25-74 years) were enrolled into the study. Twelve underwent colposcopic examination and biopsy after an abnormal result of cervical smear test (two mild dyskaryosis, five moderate dyskaryosis, three severe dyskaryosis, one suggestive of adenocarcinoma, and one suggestive of squamous carcinoma). The 28 others underwent routine hysterectomy for benign disease (menorrhagia, fibroids, prolapse, dysmenorrhoea, and dysfunctional uterine bleeding). One woman was excluded because the biopsy sample yielded less than $4 \mu \mathrm{g}$ of DNA. The amount of DNA extracted from each sample varied from 4 to $152 \mu \mathrm{g}$. As a minimum of $4 \mu \mathrm{g}$ was required for each test, it was possible to analyse 26 biopsy specimens three times, nine specimens twice, and four specimens once. In the 35 samples analysed more than once the mean result was calculated.

The chromatograms of the ${ }^{32} \mathrm{P}$ postlabelled adducts showed a diagonal zone of radioactivity (fig 1). This
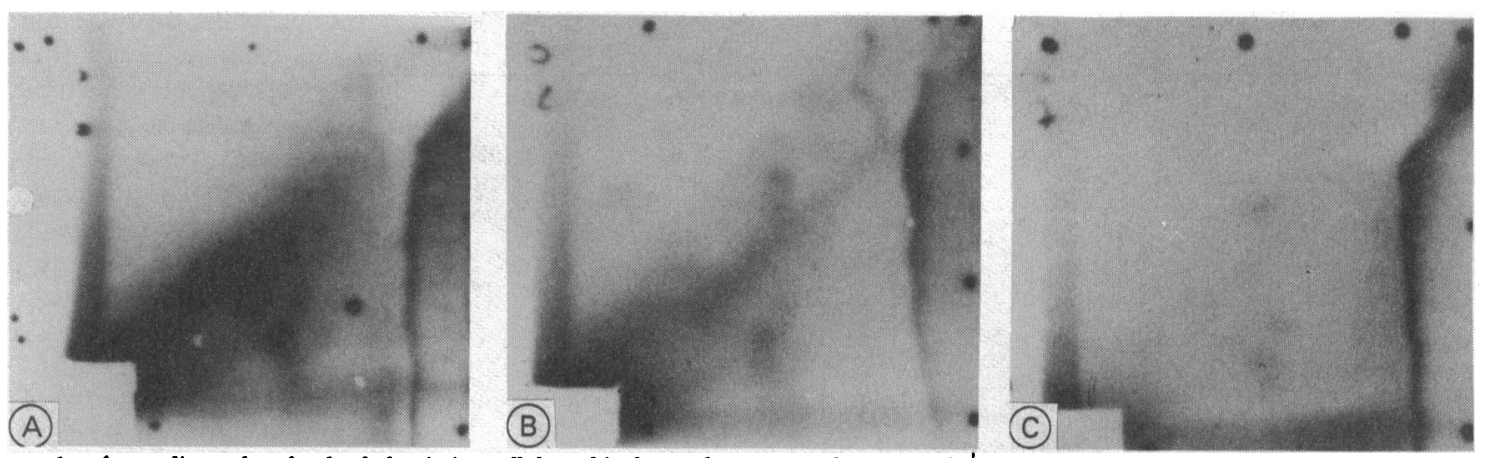

FG 1-Autoradiographs of polyethyleneimine cellulose thin layer chromatography maps of sip labelled digests of DNA from normal human cervical epithelium. Origin is located in bottom left hand comer of each chromatogram and has been excised before autoradiography for $2^{n}$ days at $-75^{\circ}$ C. Specific activity of " $P$ is same in all three. (A) Cervical DNA from smoker (11.22 adducts 10 nucleotides). (B) Cervical DNA from smoker (5.01 adducts $10^{\circ}$ nucleotides). (C) Cervical DNA from non-smoker with urinary cotinine:creatinine ratio $<0.06\left(2.15\right.$ adducts $10^{\circ}$ nucleotides). Radioactive ink, visible as small dots at peripheries of radiographs, was used to align autoradiographs with chromatograms for quantification of adducts 


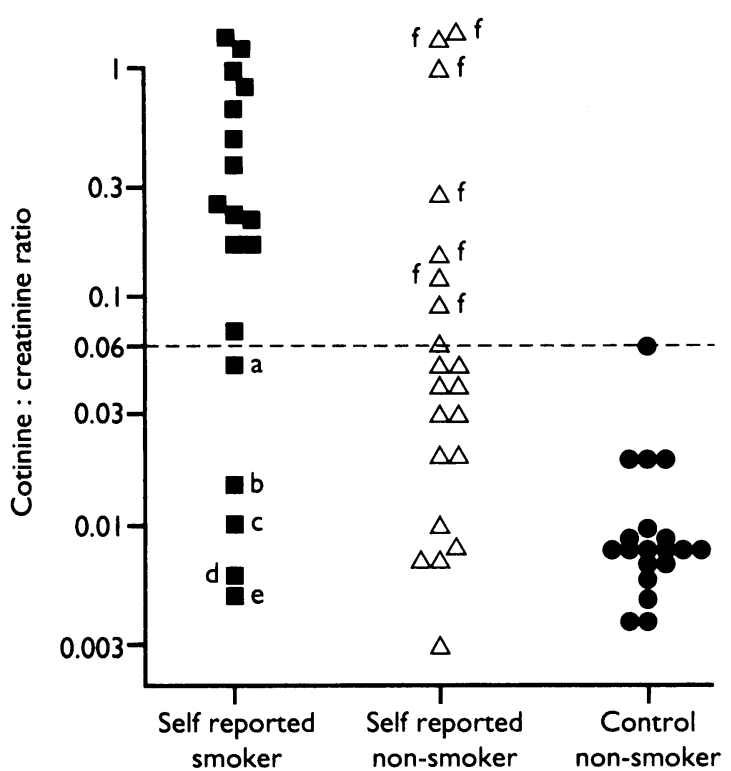

FIG 3-Urinary cotinine:creatinine ratio (nmol: $\mu \mathrm{mol}$ ) of self reported smokers $(n=18)$, non-smokers $(n=21)$, and control non-smokers $(n=$ 19): (a) smoked one cigarette a day. (b) stopped smoking six weeks before analysis. (c) stopped smoking 11 months before analysis. (d) stopped smoking 10 days before analysis. (e) stopped smoking 25 years before analysis. (f) self reported non-smokers reclassified as smokers in some analyses described in text

indicated bulky aromatic DNA adducts and was similar to that seen in previous studies of human tissue..$^{47} 15$ The range of adducts was $1 \cdot 27-14 \cdot 47$ per $10^{8}$ nucleotides (fig 2).

\section{ASSESSMENT OF SMOKING HABIT}

Of 18 women who reported having smoked cigarettes, 11 admitted to being current smokers and four to being recent (stopped within past six months) smokers; the three remaining had not smoked for at least six months. Twenty one women reported that they had never smoked. The mean (range) age of stated smokers was 36 (26-54) years and of non-smokers was 46 (25-76) years. Eight smokers and 16 non-smokers admitted to passive exposure to tobacco smoke (at work or home). There was no significant correlation between age and proportion of DNA adducts ( $p>0.05)$.

The range of urinary cotinine:creatinine ratios was $0.003-1.43$ (nmol: $\mu \mathrm{mol})$. All urinary $\mathrm{pHs}$ were within the normal range ( $\mathrm{pH} 5 \cdot 5-7 \cdot 0)$. Figure 3 shows urinary cotinine:creatinine ratios in self reported smokers, non-smokers, and non-smoking controls. Nonsmoking controls had urinary cotinine:creatinine ratios of less than 0.06 , so this value was used as a cut

Statistical analysis of DNA adducts in cervical epithelium of women according to smoking habit and result of smear test

\begin{tabular}{|c|c|c|c|c|c|}
\hline & \multicolumn{4}{|c|}{ DNA adducts $/ 10^{8}$ nucleotides } & \multirow[b]{2}{*}{$\mathrm{p}$ Value } \\
\hline & Mean & SD & Median & $\begin{array}{l}95 \% \text { Confidence } \\
\text { interval }\end{array}$ & \\
\hline $\begin{array}{l}\text { Self reported smokers }(n=18) \\
\text { Self reported non-smokers }(n=21)\end{array}$ & $\begin{array}{l}5.89 \\
3.81\end{array}$ & $\begin{array}{l}3 \cdot 72 \\
2 \cdot 13\end{array}$ & $\begin{array}{l}4 \cdot 62 \\
3 \cdot 47\end{array}$ & $\begin{array}{l}4 \cdot 04 \text { to } 7 \cdot 74 \\
2 \cdot 84 \text { to } 4 \cdot 78\end{array}$ & $p=0.048^{\star}$ \\
\hline $\begin{array}{l}\text { Self reported smokers and reclassified } \\
\text { non-smokers }(n=25) \\
\text { Non-smokers }(n=14)\end{array}$ & $\begin{array}{l}5.41 \\
3.64\end{array}$ & $\begin{array}{l}3 \cdot 37 \\
2 \cdot 27\end{array}$ & $\begin{array}{l}4 \cdot 45 \\
3.52\end{array}$ & $\begin{array}{l}4.02 \text { to } 6.80 \\
2.32 \text { to } 4.95\end{array}$ & $p=0.069^{\star} \dagger$ \\
\hline $\begin{array}{l}\text { Confirmed smokers }(n=13) \\
\text { Confirmed non-smokers }(n=14)\end{array}$ & $\begin{array}{l}5 \cdot 96 \\
3 \cdot 64\end{array}$ & $\begin{array}{l}3 \cdot 50 \\
2 \cdot 27\end{array}$ & $\begin{array}{l}4 \cdot 70 \\
3.52\end{array}$ & $\begin{array}{l}3.85 \text { to } 8.08 \\
2.32 \text { to } 4.95\end{array}$ & $\mathrm{p}=0.03^{\star}$ \\
\hline $\begin{array}{l}\text { Reported current smokers and reclassified } \\
\text { non-smokers }(n=22) \\
\text { Non-8mokers and confirmed former smokers } \\
(n=17)\end{array}$ & $\begin{array}{l}5 \cdot 71 \\
3.55\end{array}$ & $3 \cdot 47$ & $4 \cdot 62$ & $4 \cdot 17$ to $7 \cdot 25$ & $p=0.02^{\star}$ \\
\hline $\begin{array}{l}\text { Abnormal result of smear }(n=12) \ddagger \\
\text { Normal result of smear }(n=27)\end{array}$ & $\begin{array}{l}6 \cdot 02 \\
4 \cdot 22\end{array}$ & $\begin{array}{l}3 \cdot 33 \\
2 \cdot 91\end{array}$ & $\begin{array}{l}4 \cdot 70 \\
3 \cdot 47\end{array}$ & $\begin{array}{l}3.90 \text { to } 8.13 \\
3.06 \text { to } 5.36\end{array}$ & $p=0.03^{\star}$ \\
\hline
\end{tabular}

*Two tailed Mann-Whitney U test.

tOn one tailed Mann-Whitney U test (see text) $p=0.035$.

†Significant different $(p=0.05)$ also noted when smokers with abnormal result are compared with smokers with †Significant differ off point. A urinary cotinine:creatinine ratio greater than 0.06 was taken to suggest that a person had smoked in the previous $24-48$ hours. There was no significant correlation between cotinine concentrations and proportions of DNA adducts $(p>0.05)$. Such a correlation would not necessarily be expected because cotinine is a fairly short lived metabolite related to smoking and its concentration reflects exposure to tobacco smoke in the preceding 24-48 hours, whereas DNA adducts reflect a longer term exposure to genotoxic agents.

CORRELATION BETWEEN DNA ADDUCTS AND SMOKING HABIT

The women in the study were classified and the data analysed in four different ways according to whether smoking habit was judged by self reports or by cotinine:creatinine ratios. In each case the difference in numbers of DNA adducts between the groups was examined, and the table summarises the results.

Self reported smokers versus non-smokers-The median proportion of DNA adducts in women who admitted smoking was 4.62 adducts $/ 10^{8}$ nucleotides ( $95 \%$ confidence interval 4.04 to $7 \cdot 74$ ) compared with 3.47 adducts $/ 10^{8}$ nucleotides $(2.84$ to 4.78$)$ in those who reported that they did not smoke. Smokers had significantly higher proportions of DNA adducts than non-smokers $(\mathrm{p}=0.048)$.

Smokers (including self reported non-smokers reclassified as smokers as a result of urinary cotinine:creatinine ratio of >0.06) versus confirmed non-smokers-Seven women who reported that they did not smoke but whose urinary cotinine:creatinine ratio was greater than 0.06 were reclassified as smokers. The resulting median proportion of DNA adducts among the smokers was 4.45 adducts $/ 10^{8}$ nucleotides $(4.02$ to $6 \cdot 80)$ compared with 3.52 adducts $/ 10^{8}$ nucleotides (2.32 to 4.95) among confirmed non-smokers. Smokers and those reclassified as smokers had higher proportions of adducts than confirmed non-smokers $(p=0.069)$ (see fig 2 and table). This result, which was marginally significant by a two tailed MannWhitney test became significant when a one tailed test was applied $(p=0.035)$. The use of a one tailed test may be justified as the hypothesis examined is that smoking causes more DNA adducts in cervical epithelium, as in other human tissues exposed to tobacco carcinogens. ${ }^{4-7}$

Confirmed smokers (urinary cotinine:creatinine ratio $>0.06$ ) versus confirmed non-smokers (urinary cotinine: creatinine ratio $<0.06)$-All women whose urinary cotinine:creatinine ratio did not confirm their self reported smoking habit were excluded. The medium proportion of DNA adducts of confirmed smokers (self reporting and with urinary cotinine:creatinine ratio $>0.06$ ) was 4.7 adducts $/ 10^{8}$ nucleotides ( 3.85 to 8.08 ) compared with a median of 3.52 adducts $/ 10^{8}$ nucleotides $(2.32$ to 4.95$)$ for confirmed non-smokers (self reporting and with urinary cotinine:creatinine ratio $<0.06 ; \mathrm{p}=0.03$; see table).

Current smokers (either self reported or urinary cotinine: creatinine ratio $>0.06$ ) versus current non-smokers (including former smokers), whose urinary cotinine:creatinine ratio was $<0.06$ - Women who reported being current smokers at the time of the biopsy and those with a urinary cotinine:creatinine ratio $>0.06$ (current smokers) had a median proportion of 4.62 adducts $/ 10^{8}$ nucleotides $(4 \cdot 17$ to $7 \cdot 25)$. Current non-smokers (including former smokers) had a median of 3.47 adducts $/ 10^{8}$ nucleotides $(2.47$ to $4 \cdot 63)$. This was significantly lower than among current smokers $(p=$ 0.02 ; see table).

There was no significant correlation between the number of cigarettes smoked a day and the proportion of DNA adducts $(p>0.05)$. 
DIFFERENCE IN DNA ADDUCTS BETWEEN WOMEN WITH NORMAL AND ABNORMAL RESULTS ON CERVICAL SMEAR TESTS

Twelve women had an abnormal result on a smear test. Nine of these women had a urinary cotinine: creatinine ratio $>0.06$. The median adduct value in women with an abnormal result (regardless of smoking habit) was $4 \cdot 7$ adducts $/ 10^{8}$ nucleotides (3.90 to $8 \cdot 13$ ) compared with 3.47 adducts $/ 10^{8}$ nucleotides (3.06 to $5.36)$ in women with normal results $(p=0.03$; see table). Further analysis, however, showed a significant difference $(p=0.05)$ between the median proportion of adducts in the nine self reported smokers with an abnormal result $\left(6 \cdot 15 / 10^{8}\right.$ nucleotides; $4 \cdot 15$ to $\left.9 \cdot 47\right)$ and the nine with a normal result $\left(3.91 / 10^{8}\right.$ nucleotides; 1.91 to $7 \cdot 96)$. In other comparisons of smokers and non-smokers with either normal or abnormal results data sets were too small to allow analysis.

There was no correlation between cervical abnormality (mild, moderate, or severe dyskaryosis) and proportion of DNA adducts ( $p>0.05)$.

\section{Discussion}

Our results show a relation between smoking habit and the proportions of DNA adducts in cervical epithelium. The presence of adducts in cervical epithelium and the correlation with smoking habit strongly suggests that the adducts are a consequence of exposure to tobacco compounds. This provides direct biochemical evidence of potentially carcinogenic agents affecting the DNA of cervical epithelial cells.

The diagonal zones of DNA adducts observed in this study were similar to those found in previous studies that used ${ }^{32} \mathrm{P}$ postlabelling to examine human tissue exposed to tobacco..$^{475} \mathrm{~W}$ ith the procedures used here ${ }^{32} \mathrm{P}$ postlabelling will identify bulky DNA modifications such as those formed by polycyclic aromatic hydrocarbons and aromatic amines. Tobacco smokers inhale a complex mixture of chemicals, many of which have been shown to be carcinogenic in experimental animals $^{316}$ and which are therefore implicated as causative agents in lung cancer. ${ }^{45}$ Covalent modification of DNA is a critical early step in chemical carcinogenesis $^{17}$ and therefore detection of DNA adducts can provide evidence of exposure to carcinogens. All the women in the study had detectable proportions of DNA adducts whether they were smokers or non-smokers. In non-smokers this may reflect passive exposure to carcinogens in environmental tobacco smoke or to carcinogens from other environmental sources, or both.

Cotinine is a major metabolite of nicotine and has on average a half life of 19 hours. ${ }^{18}$ Only extreme acidification of urine can enhance the renal clearance of cotinine, ${ }^{18}$ but none of the urine samples had an abnormal $\mathrm{pH}$. As a result of the long half life of cotinine there is little fluctuation in its concentration in the normal smoking day so urinary cotinine concentrations are a good measure of nicotine exposure in the previous 24-48 hours. All women in the study had a recordable urinary cotinine concentration, again providing evidence for passive exposure to environmental tobacco smoke. Of the five women who reported having smoked but who had low urinary cotinine: creatinine ratios four were former smokers (the low urinary cotinine:creatinine ratios confirmed that they had given up smoking) and the fifth reported smoking only one cigarette a day (ratio $=0 \cdot 05$ ). Three out of the seven women who reported being former smokers (recent and long term) and seven out of the 21 who claimed not to have smoked had urinary cotinine: creatinine ratios above 0.06 , suggesting that they had smoked in the previous $24-48$ hours (see fig 3 ).
Deception by patients in hospital when reporting on smoking habits is well recognised. ${ }^{1920}$ As a result of this we reclassified those non-smokers with a high urinary cotinine:creatinine ratio $(>0.06)$ as smokers in some analyses.

In the analysis based on self reported smoking habits we found significantly more DNA adducts in the cervical epithelium of smokers than non-smokers $(p=$ 0.048). When those women whose urinary cotinine: creatinine ratios did not confirm their stated smoking habit (smoker or non-smoker), were excluded, this significance was increased $(p=0.03)$. Current smokers (self reported or with urinary cotinine: creatinine ratio $>0.06$ ) also had significantly higher DNA modification than non-smokers and former smokers (urinary creatinine:cotinine ratio $<0.6$; $\mathrm{p}=0 \cdot 02$ ). Confirmed long term former smokers had proportions of adducts characteristic of genuine nonsmokers, and recent former smokers had proportions characteristic of smokers - as has been previously observed. ${ }^{45}$

The women who had adduct values above $4 \cdot 7$ adducts $/ 10^{8}$ nucleotides regardless of smoking habit had had an abnormal result of a cervical smear test in over half of the cases. Nine of the 12 women with an abnormal result had an urinary cotinine:creatinine ratio greater than 0.06 , suggesting that they were current smokers. This in itself is interesting. Women with an abnormal cervical smear result had significantly higher proportions of DNA adducts than those with a normal cervical smear result $(p=0.03)$ but there was no significant relation between the degree of abnormality of the smear result and the proportion of adducts in normal epithelium. The proportion of adducts in smokers with abnormal smear results was also significantly different from that in smokers with normal cervical smear results $(p=0.05)$. Although the numbers in the study were small, the difference was significant and it confirms that modification of cervical DNA by components of tobacco smoke may be causal in cervical dyskaryosis.

Women with high proportions of adducts may have an increased susceptibility to cervical cancer. Prospective studies of women with a high proportion of modified cervical DNA are essential to establish the risk. This could be done by detecting the DNA adducts from scrape samples of exfoliative cervical cells as previously described. ${ }^{21}$

With the number of young women who smoke currently increasing in the United Kingdom (particularly young women aged $15-25$ years) ${ }^{22-24}$ the potential for a rise in the incidence of cervical cancer could be expected. If tobacco smoking was stopped permanently there could be a $20-25 \%$ decrease in cases of cervical cancer in Western countries. ${ }^{25}$

In 1986 the International Agency for Research on Cancer determined that there was not enough evidence to conclude that smoking is a cause of cervical cancer. ${ }^{3}$ Our findings are consistent with the proposal put forward by Winkelstein, ${ }^{1}$ that smoking is a causative agent of cervical cancer.

We thank Meadhbh $\mathrm{Ni}$ Shé (Haddow Laboratories, Institute of Cancer Research) for help in setting up the ${ }^{32} \mathrm{P}$ postlabelling analysis and Dr J Powell and M.Sian (department of surgery, Charing Cross Hospital) for their advice with urinary cotinine assays. We also thank the staff and patients of the Samaritan Hospital for Women, London, for their assistance in this study. This work was supported in part by the Cancer Research Campaign. AMS is supported by grants from the Cancer Research Campaign and the British Council.

\footnotetext{
1 Winkelstein W Jr. Smoking and cervical cancer-current status: a review. Am J Epidemiol 1990;131:945-57.

2 Brisson J, Roy M, Fortier M. Condyloma and intraepithelial neoplasia of the
} uterine cervix: a case-control study. Am f Epidemiol 1988;128:337-42. 
3 International Agency for Research on Cancer. Monograph on the evaluation of carcinogenic risk of chemicals in humans. Vol 38. Tobacco smoking. Lyon: IARC, 1986.

4 Phillips DH, Hewer A, Martin CN, Garner RC, King MM. Correlation of DNA adduct levels in human lung with cigarette smoking. Nature 1988;336:790-2.

5 Phillips DH, Schoket B, Hewer A, Bailey E, Kostic S, Vincze I. Influence of cigarette smoking on the levels of DNA adducts in human bronchial epithelium and white blood cells. Int I Cancer 1990;46:569-75.

6 Dunn BP, Vedal S, San RH, Kwan WF, Nelems B, Enarson DA, et al. DNA adducts in bronchial biopsies. Int $\mathcal{F}$ Cancer 1992;48:485-92.

7 Randerath E, Millar R, Mittal D, Avitts TA, Dunsford HA, Randerath K. Covalent DNA damage in tissues of cigarette smokers as determined by 'P-postlabelling assay. $\mathcal{F}$ Natl Cancer Inst 1989;81:341-7.

8 McCann MF, Irwin DE, Walton LA, Hulka BS, Morton Jle, Axelrad CM. Nicotine and cotinine in the cervical mucus of smokers, passive smoker and nonsmokers. Cancer Epidemiology Biomarkers and Prevention 1992;1: $125-9$.

9 Sasson IM, Haley NJ, Hoffmann D, Wynder EL, Hellberg D, Nilsson S Cigarette smoking and neoplasia of the uterine cervix: smoke constituents in cervical mucus. $N$ Engl $\mathcal{H}$ Med 1985;312:315-6.

10 Schoket B, Horkay I, Kósa A, Páldeák L, Hewer A, Grover PL, et al. Formation of DNA adducts in the skin of psoriasis patients, in human skin in organ culture and in mouse skin and lung following topical application of in organ culture and in mouse skin and lung following topic

11 Gupta R. Enhanced sensitivity of "P-postlabelling analysis of aromatic carcinogen: DNA adducts. Cancer Res 1985;45:5656-62.
conta

12 Gupta R, Reddy MV, Randerath K. "P-postlabelling analysis of nonradioactive aromatic carcinogen-DNA adducts. Carcinogenesis 1982;3 1081-92
13 Reddy MV, Randerath K. Nuclease Pl-mediated enhancement of sensitivity of "P-postlabelling test for structurally diverse DNA adducts. Carcinogenesis 1986;7:1543-51.

14 Feyerabend C, Russell MAH. Rapid gas chromatography determination of cotinine in biological fluids. Analyst 1980;105:998-1001.

15 Cuzick J, Routledge MN, Jenkins D, Garner RC. DNA adducts in different tissues of smokers and non-smokers. Int $\mathcal{F}$ Cancer 1990;45:673-8.

16 Hoffmann D, Hecht SS. Advances in tobacco carcinogenesis. In: Cooper CS, Grover PL, eds. Handbook of experimental pharmacology. Vol 94/1. Chemical

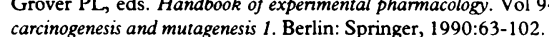

17 Miller EC, Miller JA. Searches for ultimate chemical carcinogens and their reactions with cellular macromolecules. Cancer 1981;47:2327-45.

18 Benowitz NL, Kuyt F, Jacob III P, Jones RT, Osman A-L. Cotinine disposition and effects. Clin Pharmacol Ther 1983;34:604-11.

19 Sillet RW, Wilson MB, Malcolm RE, Ball KP. Deception amongst smokers. BMF 1978;ii:1185-6.

20 Wilcox RG, Hughes J, Roland J. Verification of smoking history in patients after infarction using urinary nicotine and cotinine measurements. $B M$ 1979;ii:1026-8.

21 Phillips DH, Hewer A, Malcolm ADB, Ward P, Coleman DV. Smoking and DNA damage in cervical cells. Lancet 1990;335:417.

22 Action on Smoking and Health (ASH). Teenage girls and smoking. London: ASH, 1986.

23 Office of Population Censuses and Statistics. Cigarette smoking 1972-1990. OPCS Monitor 1991;SS91/3.

24 Royal College of Physicians Working Party. Smoking and the young (5th report). London: Royal College of Physicians, 1992.

25 Sasco AJ. World burden of tobacco-related cancer. Lancet 1991;338:123-4.

(Accepted 29 March 1993)

\section{Protection of children by their mothers against sunburn}

\section{Paul Jarrett, Caroline Sharp, Janet McLelland}

\section{Department of \\ Dermatology, Sunderland \\ Royal Infirmary, \\ Sunderland SR2 7JE \\ Paul Jarrett, senior house \\ officer \\ Caroline Sharp, clinical \\ assistant \\ Janet McLelland, consultant \\ dermatologist}

Correspondence to:

Dr McLelland.

BMF 1993;306:1448
There is evidence that episodes of sunburn increase the risk of developing malignant melanoma, ${ }^{12}$ especially sunburn in childhood. ${ }^{3-5}$ In Australia there have been extensive public education campaigns alerting people to the dangers of excessive sunlight exposure, including the slip (on a shirt), slop (on sun cream), and slap (on a hat) campaign. In Britain there has been less publicity, but the incidence of malignant melanoma is increasing.

This study looks at the practices of mothers in Sunderland (a town not noted for its sunny climate) in protecting their children from the sun and the incidence of sunburn among these children.

\section{Methods and results}

During September and October 1991, 200 mothers attending the paediatric department of Sunderland District General Hospital were interviewed. They were questioned about their youngest children, up to a maximum of three per family, and only those children aged under 20 were included. The mothers were asked how many times their children had been sunburnt (defined as more than $1 \%$ of the total body area going red several hours after exposure to the sun) in the previous year.

Information on 416 children was obtained, of whom 159 had been sunburnt at least once, 150 having been burnt in Britain. Of the 416 children, 75 had been burnt once in the previous year; 29 had been burnt

Children of different ages, exposed to the sun without a shirt, with a hat worn, or with sun cream applied

\begin{tabular}{lcccccc}
\hline & \multicolumn{7}{c}{ Children's age (years) } \\
\cline { 2 - 7 } & $\begin{array}{c}<1 \\
(n=28)\end{array}$ & $\begin{array}{c}1-2 \\
(n=71)\end{array}$ & $\begin{array}{c}3-4 \\
(n=63)\end{array}$ & $\begin{array}{c}5-9 \\
(n=129)\end{array}$ & $\begin{array}{c}10-15 \\
n=103)\end{array}$ & $\begin{array}{c}16-20 \\
(n=22)\end{array}$ \\
\hline $\begin{array}{l}\text { No (\%) exposed to sun without shirt at } \\
\quad \text { least once }\end{array}$ & $4(14)$ & $37(52)$ & $52(83)$ & $106(82)$ & $81(79)$ & $13(59)$ \\
$\begin{array}{l}\text { No (\%) with sun cream applied at least } \\
\text { once }\end{array}$ & $8(29)$ & $42(59)$ & $41(65)$ & $68(53)$ & $60(58)$ & $8(36)$ \\
No (\%) worn hat at least once in sun & $24(86)$ & $62(87)$ & $42(67)$ & $62(48)$ & $44(43)$ & $3(14)$ \\
\hline
\end{tabular}

twice, 17 had been burnt three times, eight had been burnt four times, and 30 had been burnt five or more times. Of the 163 sunburn incidents in the 1-9 year age group, 18 occurred in a paddling pool, 57 occurred while playing at home but not in a paddling pool, and 49 occurred at the seaside (14 on the beach at Sunderland). Only seven children were burnt while sunbathing, and all were over 10 years old.

Altogether $293(70 \%)$ of the children in the survey had been exposed to the sun without a shirt, $227(54 \%)$ had had sun cream applied at least once in the previous year and $237(57 \%)$ had worn a hat in the sun at least once. The table shows the analysis of these factors by age; infants aged $<1$ year were most protected against the sun. Boys were more likely than girls to remove their shirts in the sun (boys:girls $=1 \cdot 7: 1$ ), but there was little difference between the sexes in hat wearing (boys:girls $=1 \cdot 1: 1$ ) and the application of sun cream (boys:girls $=1 \cdot 2: 1$ ). There was no relation between skin type and the use of a shirt, sun cream, or a hat.

\section{Comment}

We found a high incidence of sunburn among the children in the study with $38 \%$ of them having been sunburnt in the previous year, nearly always in Britain. Children under 1 year old tended to be well protected, but protection against the sun declined with age. Skin type did not affect a child's likelihood of wearing a shirt, sun cream, or a hat, suggesting that the increased risk of sunburn in a fair skinned child was not perceived by its mother. There is a need for more public education about the dangers of sunlight, in particular to children, in this country.

We thank the Paediatric Department, Sunderland District General Hospital, for permission to study patients.

1 Mackie RM, Aichison T. Severe sunburn and subsequent risk of primary cutaneous malignant melanoma in Scotland. Br f Cancer 1982;46:955-60. Green A, Sinskind V, Bain C, Alexander J. Sunburn and malignant melanoma. Br f Cancer 1985;51:393-7.

3 Holman CD, Armstrong BK. Cutaneous malignant melanoma and indicators of total accumulated exposure to the sun: an analysis separating histogenetic total accumulated exposure to the sun:
types. $I$ Natl Cancer Inst 1984;73:75-82.

4 Osterlind A, Tucker MA, Stone BJ, Jensen OM. The Danish case control study of cutaneous malignant melanoma. II: Importance of UV-light exposure. of cutaneous malignant mel
Int 9 Cancer 1988;42:319-24.

Int f Cancer 1988;42:319-24.
5 Weinstock MA, Colditz GA, Willett WC, Stampfer MJ, Bronstein BR, Mihm $\mathrm{MC}$, et al. Non-familial cutaneous melanoma incidence in women associated with sun exposure before 20 years of age. Pediatrics 1989;84:199-204. 